\title{
AS DISPUTAS PELA INTERPRETAÇÃO DA LEI DE ANISTIA DE 1979
}

\author{
Janaina de Almeida Teles ${ }^{1}$
}

\section{A campanha pela anistia ampla, geral e irrestrita e a votação da lei}

A campanha pela anistia ampla, geral e irrestrita ganhou força com a formação dos Comitês Brasileiros pela Anistia (CBAs), em 1978, e se constituiu num movimento político que recebeu certo apoio popular promovendo extensa divulgação pública das denúncias sobre os abusos aos direitos humanos cometidos pela ditadura. O objetivo era o de desgastar o regime, que apresentava sinais de enfraquecimento. Os CBAs assumiram as reivindicações dos familiares de mortos e desaparecidos políticos: o esclarecimento sobre as torturas, mortes e desaparecimentos forçados; a restituição dos restos mortais; a atribuição das responsabilidades e a punição dos torturadores; o desmantelamento do aparelho repressivo e o fim das "leis de

\footnotetext{
${ }^{1}$ Doutoranda em História Social na Faculdade de Filosofia, Letras e Ciências Humanas da USP e pesquisadora associada do Laboratório de Estudos sobre a Intolerância (LEI) da FFLCH-USP. Autora do livro Os herdeiros da memória: a luta dos familiares de mortos e desaparecidos políticos no Brasil (no prelo) e coorganizadora do Dossiê Ditadura: Mortos e Desaparecidos Políticos no Brasil (1964-1985). São Paulo, IEVE/Imprensa Oficial, 2009, entre outros.
} 
exceção". O movimento bateu de frente com as propostas de projeto de lei de anistia do governo e de "transição política", marcadas pela perspectiva da conciliação. ${ }^{2}$

Na madrugada de 22 de agosto de 1979, 800 soldados à paisana das polícias do Exército e da Aeronáutica ocuparam as galerias do Congresso, mas os militantes em defesa da anistia conseguiram ocupar o local à tarde. ${ }^{3} \mathrm{~A}$ imprensa divulgara a ordem emitida pelo Palácio do Planalto, era imprescindível votar o substitutivo de Ernani Satyro tal qual ele chegou ao Congresso, caso contrário, haveria veto total do presidente ao projeto de anistia. $^{4}$

As discussões entre o MDB e os CBAs evoluíram para um acordo de apoio à Emenda no.7 do projeto de lei de anistia do governo, assinada pelos deputados Ulysses Guimarães (presidente do MDB), Freitas Nobre (líder da minoria na Câmara) e pelo senador Paulo Brossard (líder da minoria no Senado), apresentada em 9 de agosto de $1979 .{ }^{5}$ Dalmo Dallari, jurista da Comissão de Justiça e Paz/SP, e José Paulo Sepúlveda Pertence, então vice-presidente do Conselho Federal OAB, participaram da sua redação. Seus principais aspectos eram os seguintes: rejeição da reciprocidade na concessão da anistia (art.1 ${ }^{\circ}$, $\left.\S 2^{\circ}\right)$, propunha a anistia aos perseguidos políticos; a instauração de inquérito para apurar as circunstâncias dos desaparecimentos políticos, (art.15), mas propunha a concessão de declaração de morte presumida para os desaparecidos políticos (art.16), sem

\footnotetext{
${ }^{2}$ Greco, Heloísa Amélia. Dimensões fundamentais da luta pela anistia. Belo Horizonte, Doutorado em História, FAFICH/UFMG, 2003.

${ }^{3}$ Nas galerias, a disputa das torcidas, Jornal do Brasil, 23/08/79, p. 4; Presença de soldados leva a protesto, Folha de S. Paulo, 23/08/79.

${ }^{4}$ Congresso aprova anistia hoje, Arena decide fechar questão e Sarney não atende $M D B$, O Estado de S. Paulo, 22/08/79, p.4; Governo não aceita novas emendas, Folha de S. Paulo, 22/08/79, p. 4.

${ }^{5}$ Inicialmente, os CBAs apoiaram a Emenda 1, p. 53-7. Ver Emenda 7, de 09/08/79, p. 71-4. In: Comissão Mista sobre a Anistia. Anistia, v.I, Op. cit.
} 
investigação prévia, similar à declaração de ausência do substitutivo da ARENA. ${ }^{6}$

A rejeição à concessão de anistia aos torturadores ficou explicitada na parte inicial do texto, ao detalhar os beneficiários da anistia (art. $1^{\circ}$.), mas não deixou margem a dúvidas no parágrafo $2^{\circ}$, conforme o texto: "Excetuam-se dos benefícios da anistia os atos de sevícia ou de tortura, de que tenha ou não resultado morte, praticados contra presos políticos". Além disso, a proposta embutia a regulamentação da lei no texto para que não houvesse tergiversações na sua aplicação. Denunciava e combatia também o caráter discriminatório da proposta do governo que determinava como excluídos do alcance da anistia "os condenados pela prática de terrorismo, assalto, sequestro e atentado pessoal" ( $\left(2^{\mathrm{o}}\right.$ do art. $\left.1^{\circ}\right) .^{7}$

Durante o mês de agosto, o MDB e o movimento pela anistia convergiram para posições que assumiam a votação do projeto de lei no Congresso: a tática a ser seguida nas sessões conjuntas do Congresso Nacional durante a discussão e aprovação do projeto foi a de propor destaque para o substitutivo do partido. Devido à maioria alcançada pelos seus 22 senadores biônicos, sabia-se da vitória da ARENA. Em seguida, pediriam destaque para a emenda do deputado Djalma Marinho (ARENA/RN), presidente da Comissão de Justiça da

${ }^{6}$ V. Emenda 7, Op. cit., pp.71-4; Projeto do MDB exclui torturadores da anistia e Substitutivo do MDB não deixa ninguém nas prisões, Jornal do Brasil, 05/08/79, p. 8; Prazo para emendar anistia termina hoje, Jornal do Brasil, $10 / 08 / 79$, p. 2.

7 “Art. 1․ É concedida anistia a todos quantos, até a sua data da publicação desta lei, cometeram crimes políticos ou conexos, aos que tiveram seus direitos políticos suspensos, aos juízes, aos dirigentes sindicais, aos estudantes, aos servidores públicos civis e militares da União, dos Estados, dos Municípios, dos Territórios e do Distrito Federal, aos empregados das sociedades de economia mista, empresas públicas e fundações instituídas pelo Poder Público, punidos por motivo político, com fundamento ou não nos atos institucionais e complementares." COMISSÃo MISTA sobre a Anistia. Anistia, v.I, Op. cit., p. 71. 
Câmara. Essa emenda poderia derrubar as exceções da anistia do governo e conseguir a adesão de dissidentes do partido do governo. Rejeitariam em plenário o substitutivo do relator da Comissão Mista de Anistia, Ernani Satyro, seguida de apresentação de declaração de voto. ${ }^{8}$

A emenda Djalma Marinho foi aceita, mas os CBAs de Minas Gerais e São Paulo foram refratários por considerarem que a proposta contemplava a reciprocidade..$^{9}$ De acordo com a historiadora Heloísa Greco, o apoio à emenda foi uma surpresa entre as modificações de posição dos movimentos de anistia. ${ }^{10}$ A emenda suprimia os dois parágrafos do artigo $1^{\circ}$. da proposta do governo e propondo apenas um, no qual não acrescentava nada referente aos crimes conexos, mas refutava a ausência de isonomia na concessão da anistia, suprimindo a exclusão dos condenados, com sentenças transitadas em julgado (sem direito a recurso), pela prática de "terrorismo, assalto, sequestro e atentado pessoal" $\left(\S 2^{\circ}, \operatorname{art}^{\circ} 1^{\circ}\right) .^{11}$

A vitória do governo foi garantida pela sua maioria numérica no Congresso. ${ }^{12}$ Contribuíram também as rígidas

\footnotetext{
${ }^{8}$ Emenda Djalma Marinho (ARENA/RN). In: ComIssão Mista sobre a Anistia. Anistia, v.I, Op. cit., p. 115; Uma discussão sobre tática parlamentar com o Dr. Waldir Pires, ex-consultor geral da República no governo João Goulart, e Ulysses Guimarães, presidente do MDB, visita os presos políticos do Rio de Janeiro ( $23^{\circ}$ dia da greve de fome). In: Viana, Gilney e Cipriano, Perly. Fome de Liberdade. Relato dos presos políticos. Vitória, Fundação Ceciliano Abel e Almeida, 1992, pp.159-60 e pp. 163-4; e SARDENBERG, Carlos Alberto. O girondino Djalma, Isto É, 29/08/79, p. 11.

${ }^{9}$ Ver Greco, Heloísa. Op. cit., p. 246; e Caravanas levam cartazes. Estado de Minas, 22/08/79, p. 2.

${ }^{10}$ Viana, Gilney e Cipriano, Perly. Op.cit., p.208; Até o final, presos mantinham esperança, Folha de S. Paulo, 23/08/79; Arena decide fechar questão, O Estado de S. Paulo, 22/08/79, p. 4.

${ }^{11}$ Diversas emendas propunham a supressão do $\S 2$ ${ }^{\circ}$, do art.1ํㅡ, ver, por exemplo, as de no 61 ou 63. Comissão Mista sobre a Anistia. Anistia, v.I, Op. cit., p. 121-29.

${ }^{12}$ Eram 231 deputados arenistas, 189 do MDB e, 41 senadores contra 26, apoiados pelos 22 senadores biônicos. Governo confia na maioria do Senado,
} 
normas regimentais, o complicado ritual de votação. Estavam muito presentes na memória as cassações de parlamentares. Em janeiro de 1976, uma onda de cassações atingiu os deputados gaúchos Nadir Rosseti e Amauri Muller. Em abril daquele ano, o deputado Lysâneas Maciel foi cassado depois de discursar no Congresso: "[...] mais doloroso e grave que as cassações, é que com elas estamos nos acostumando à falta de liberdade, à censura, ao desaparecimento de brasileiros, sua tortura e morte presumida." Em seguida, o deputado Alencar Furtado, líder do MDB, tratou das famílias de desaparecidos políticos num programa de TV, referindo-se às "viúvas e os órfãos do talvez e do quem sabe" e foi cassado. Em 1‥ de abril de 1977, o Congresso havia sido fechado durante 15 dias, quando o general Ernesto Geisel impôs reformas no judiciário e eleitorais, estabelecendo os senadores biônicos por meio do "Pacote de Abril". ${ }^{13}$

O resultado da votação surpreendeu, revelando alguma perda de controle por parte do governo. A proposta para dar preferência (destaque) ao substitutivo do MDB foi derrotada por 209 votos contra 194, com o apoio de 12 arenistas dissidentes. Após obter o destaque, a emenda Djalma Marinho por pouco não foi vitoriosa, recebeu 201 votos a favor e 206 contra, conseguindo o apoio de 14 arenistas.

Por fim, a anistia do governo foi aprovada pela votação dos líderes dos dois partidos. Os líderes do MDB na Câmara e no Senado, Freitas Nobre e Paulo Brossard, aprovaram o projeto,

O Globo, 22/08/79; Arena decide fechar questão, O Estado de S. Paulo, 22/08/79, p. 4.

${ }^{13}$ Em 24/06/76, o governo havia sancionado a "Lei Falcão", que diminuía muito o acesso da oposição à TV. E havia a ameaça do dispositivo regimental que determinava a perda de mandato para os parlamentares que desrespeitassem as diretrizes partidárias, ainda que essa medida não pudesse ser utilizada, pois não estava registrada no Tribunal Superior Eleitoral. V. Teles, Janaina de A. Os herdeiros da memória. Op. cit. 
não sendo possível a votação nominal. Esta atitude da liderança provocou críticas dos CBAs e do senador Teotônio Vilela. A declaração de voto contrário de 29 dos 189 deputados do MDB denunciava a falta de isonomia na concessão da anistia, mas sedimentava a interpretação de que "[...] anistia-se irrestritamente os torturadores e parcialmente os opositores do regime. [...] nos manifestamos contra o substitutivo ao projeto de 'anistia' do governo. Recusando nosso voto para sua legitimação [...]." ${ }^{14}$

O projeto de Lei de Anistia dos militares foi sancionado no dia 28 de agosto pelo general João Batista Figueiredo. Prevaleceu a interpretação de que a anistia teria sido recíproca, favorecendo vítimas e algozes, realçando os conhecidos argumentos de que se tratava de uma "guerra", em que os dois lados cometeram "excessos", equiparando injustamente a tortura praticada pelos agentes do Estado às ações políticas dos opositores da ditadura.

Como decorrência desse processo, no Brasil, o trabalho de luto relacionado ao período da ditadura não teve o caráter social ou coletivo como foi e é vivenciado em outros países latinoamericanos. Diante de um passado que permanece em segredo, sem uma ampla mobilização social de reivindicação pelo esclarecimento dos abusos dos direitos humanos ocorridos no período, sem os rituais, mecanismos e leis que garantam o "direito à verdade e à justiça", esses agravos sem solução continuam a exigir um trabalho coletivo de simbolização para impedir que o trauma histórico produza ressentimentos ou outras formas de "abusos da memória".

Os entraves políticos que impediram a aprovação de uma Lei de Anistia "ampla, geral e irrestrita" para os presos políticos

\footnotetext{
${ }^{14}$ Comissão Mista sobre a Anistia. Anistia, v.II, Op. cit., Ata da $163^{a}$ sessão conjunta, realizada em 22/08/79 (aprovação da matéria), pp. 237-8. Grifo meu. E Promessa de que a luta vai continuar, Folha de S. Paulo, 23/08/79; e Greco, Heloísa. Op. cit., p. 254-5.
} 
e a investigação dos crimes cometidos pela ditadura, considerando que as ações civis e processos administrativos existentes não realizaram a produção de provas com a amplitude necessária e não buscaram a responsabilidade individual, dificultam a adoção de uma "postura de escuta" por parte da sociedade brasileira, o enfrentamento desse passado e o trabalho de luto.

\section{As disputas pela interpretação da lei de anistia}

Logo após a Lei da Anistia ser sancionada advogados e juristas expressaram suas análises sobre a extensão de seus efeitos. O debate jurídico a respeito da interpretação da anistia que considerava os torturadores excluídos de seus beneficiários ocorreu em círculos restritos, prevalecendo a notória intenção dos militares e seus aliados de contemplá-los. Vale recuperar parte desse debate e disputas, a fim de compreendermos melhor a apreciação do tema feita pelo STF, quando da análise da Arguição de Descumprimento de Preceito Fundamental (ADPF) 153, em abril de 2010, proposta pelo Conselho Federal da OAB, que questionou a legitimidade e a legalidade da lei 6.683 (a Lei de Anistia), à luz da legislação de exceção de então e da Constituição de 1988, bem como dos Tratados Internacionais de Direitos Humanos.

No início de 1980, advogados e juristas já questionavam sua legitimidade e legalidade, bem como os erros jurídicos de interpretação que a considera recíproca. O texto da lei, embora pouco claro, determina a anistia "aos crimes políticos ou conexos a estes" ( $\S 1^{\circ}$, art. $\left.1^{\circ}\right)$, ou seja, os crimes de qualquer natureza relacionados àqueles praticados por motivação política, ou seja, os crimes previstos na Lei de Segurança Nacional (LSN). O crime conexo seria o assalto a banco ou roubo de carro realizado por militantes políticos como apoio à luta armada.

Ademais, como a lei não anistiou aqueles que foram condenados pela prática de terrorismo, assalto, sequestro e atentado pessoal $\left(\S 2^{\mathrm{o}}, \operatorname{art.} 1^{\circ}\right)$, vários presos políticos foram libertados 
devido à redução das penas estabelecidas pela LSN reformulada em 1978. Não foram absolvidos nem anistiados, saíram das prisões em liberdade condicional. A anistia não foi de "mão dupla" e apenas os torturadores permaneceram imunes aos julgamentos. ${ }^{15}$

Nilo Batista, criminalista e professor de Direito, detevese na definição de crime político e conexo a fim de demonstrar que a tortura estava fora dessa classificação. O crime político havia sido bastante discutido durante os debates em torno da votação da lei. ${ }^{16}$ Para ele, era "evidente que a anistia tinha o sentido de corrigir uma lei disforme e monstruosa, que era o Decreto-lei 898, de 29 de setembro de 1969 [a LSN], com seu elenco de incriminações estapafúrdias e penas atrozes, decretolei contra o qual se levantava toda a consciência jurídica nacional" ${ }^{\prime 17}$ Sua tese, internacionalmente aceita, era de que o crime comum, para ser considerado conexo ao político, deve guardar uma relação de subordinação com este, e concluiu que a anistia alcançava "não só os delitos comuns que sejam meio para a prática de crimes políticos, ou para escapar às penas desses (conexão em sentido objetivo), bem como quaisquer outros (ainda que não relacionados objetivamente com um crime político), desde que praticados com motivação política" - apontando o critério subjetivo para a definição de crime conexo. Além disso, a anistia

\footnotetext{
${ }^{15}$ Desde a Constituinte de 1988 a abrangência da anistia vem se ampliando num processo ainda em andamento. Ver <www.planalto.gov.br/CCIVIL/ leis/L6683compilada.htm>.

16 "Para sua caracterização, não se leva[va] em conta a forma, mas sim o conteúdo, isto é, a motivação que o determinou. Foram crimes políticos, à luz das leis de exceção em vigor, especialmente à luz da Lei de Segurança Nacional, todos os atos, pacíficos ou armados, cruentos ou incruentos de oposição ao regime". V. Martins, Roberto Ribeiro. "Anistia: um balanço". Encontros com a Civilização Brasileira, Rio de Janeiro, 8, fev./1979, p. 205.

17 Batista, Nilo. "Aspectos Jurídico-Penais da Anistia". Encontros com a Civilização Brasileira, Rio de Janeiro, 19, jan./1980, p. 197.
} 
não se estendeu aos delitos comuns sem conexão com os crimes políticos, pois:

[...] deverá verificar-se que tradicionalmente a anistia se dirige a delitos políticos. Ensinava Aloysio de Carvalho Filho: 'a índole do instituto, efetivamente, repele a extensão aos delitos comuns'. Afirma Railda Saraiva de Moraes: 'destina-se a anistia, por sua própria natureza, aos crimes políticos, embora aplicável, por vezes, a crimes comuns, o que é repelido pela melhor doutrina ${ }^{\prime 18}$

Nilo Batista destacava que a conexão "[...] é um instituto do direito processual penal; a presença de certas circunstâncias (há conexão intersubjetiva, objetiva e probatória) sugere a reunião dos processos pertinentes a vários delitos, e prorroga a competência do juiz de um deles para que processe e julgue os demais. O conceito de crime conexo a crime político é um conceito material e não processual, que diz com a própria natureza do crime." E pontuava que para a conceituação do delito conexo ao delito político, prevalece o critério objetivo, baseado na relação meio-fim. O critério subjetivo, a motivação, costuma ser utilizado de modo restritivo, como elemento limitador, para definir o que não é crime conexo ao crime político.

Batista chamou atenção ainda para a questão da isonomia na concessão da anistia: "O legislador não concedeu anistia a autores ou partícipes de assalto, sequestro, atentado pessoal e terrorismo, mesmo quando conexos a crimes políticos. Formulação que fere o princípio da reserva legal, por consistirem em incriminações vagas e indeterminadas. Segundo ele, ocorreu nesse caso, uma "injustiça material", pois pessoas condenadas pelos mesmos crimes pelos quais outros não chegaram a ser condenados definitivamente não foram anistiadas. Tratava-se, portanto, "de submeter a matéria à justiça". Ressaltando que o

${ }^{18}$ Idem, ibidem, p. 199-200. 
$\mid 80$ |

As disputas pela interpretação da lei de anistia de 1979

crime comum não conexo ao crime político estava excluído da anistia. $^{19}$

Em agosto de 1979, logo após a publicação da Lei de Anistia, a Ordem dos Advogados do Brasil (OAB) manifestou-se, declarando que a falta de objetividade do texto e a exclusão dos chamados "terroristas" dos benefícios da lei rompiam com a tradição jurídica brasileira. A entidade pretendia questionar na justiça a constitucionalidade do parágrafo $2^{\circ}$., do artigo $1^{\underline{o}}$. da lei, baseada no parecer de julho de 1979, de José Paulo Sepúlveda Pertence, que não questionava a suposta reciprocidade contida no projeto do governo, mas a discriminação arbitrária existente entre condenados e não condenados por envolvimento na luta armada. ${ }^{20}$

De acordo com o parecer, "[...] não se pode sustentar a sério a legitimidade jurídica ou moral de pretender engalanarse com a grandeza da anistia [...] um projeto que discrimina entre autores não condenados e autores já condenados pelos mesmos crimes políticos, para excluir estes dos benefícios da anistia que se estenderão àqueles". Para Sepúlveda Pertence, a discriminação

\footnotetext{
${ }^{19}$ Id., ib., p. 200-4. Com relação às ações civis, Batista apontava uma perspectiva: ações regressivas. Se o Estado for declarado culpado e obrigado a indenizar a família de uma vítima da tortura, assassinato ou desaparecimento forçado, o próprio Estado deveria cobrar do torturador o pagamento da indenização. Ver Moretzshon, Sylvia. "A conexão tortura. Haverá na lei de anistia uma brecha para a punição dos que cometeram crimes contra os presos políticos?" Jornal do Brasil, Caderno B Especial, 12/ 04/87, p. 8. V. a ação judicial do MPF/SP, de 2008, contra Carlos Alberto Brilhante Ustra e Audir Maciel, comandantes do DOI-Codi/SP nos anos 1970.

20 "OAB acha que exclusão de terrorista rompe tradição". O Globo, 30/08/79, p. 6; "Consideração do Dr. José Paulo Pertence". In: Comissão MISTA sobre anistia. Anistia. Vol. II, Op.cit., p.432. Durante o julgamento da ADPF 153, no STF, o parecer foi citado como prova da aceitação, por parte da OAB, do acordo político que garantiu a anistia aos torturadores. O relator, Eros Grau, e diversos ministros omitiram os esforços para obter o destaque para a emenda 7.
}

Um balanço crítico da redemocratização no Brasil 
era "politicamente amoral" e ofensiva do princípio constitucional da igualdade. Assim, poderia "[...] a norma se transformar em fonte de arbítrio judicial, mercê da referência, para excetuá-los da anistia, aos condenados por crimes de terrorismo, que é figura penal inexistente nas últimas leis de segurança nacional". ${ }^{21} \mathrm{~A}$ $\mathrm{OAB}$, porém, não levou adiante a iniciativa de questionar a constitucionalidade Lei de Anistia.

Sepúlveda Pertence, embora não questionasse a reciprocidade da Lei de Anistia, apresentou sua posição a respeito da extensão da anistia aos torturadores. Segundo ele, o texto da lei ampliou de modo inédito o conceito de crime comum conexo a crimes políticos, "[...] para beneficiar com a anistia, não apenas os delitos comuns de motivação política (o que encontra respaldo nos precedentes) [...]", mas, também aqueles que tenham qualquer relação com o crime político com o "[...] sentido de prodigalizar a anistia aos homicídios, violências e arbitrariedades policiais de toda a sorte, perpetrados nos desvãos da repressão política", destacando o caráter injusto da lei:

Não há, com efeito, como aceitarmos - à luz dos valores do Estado de Direito Democrático, que integram o compromisso da Ordem perante a nação - que a condenação ética do terrorismo sirva para excluir os contestatários de uma ditadura, embora violentos, dos benefícios da mesma lei de anistia, na qual a mais forte e universal condenação ética da tortura policial não foi óbice à extensão da impunidade legal aos crimes dos que a tornaram rotina, no procedimento da repressão aos adversários do regime. ${ }^{22}$

${ }^{21}$ Idem, ibidem, p. 434.

${ }^{22} I d ., I b .$, p. 433. 
| 82 |

As disputas pela interpretação da lei de anistia de 1979

O parecer da seção de São Paulo da OAB, porém, propunha uma nova redação do artigo $1^{\circ}$. do projeto de lei de anistia, e contestava a reciprocidade com a seguinte justificativa:

O projeto, de forma esdrúxula, procura ser inovador em matéria processual penal, ao estabelecer um conceito próprio e específico de crime conexo. Com esta nova categoria estende-se, por meio de eufemismos, a anistia às violências ocorridas na atuação repressiva, definidas em projeto, de forma sibilina, como crimes "de qualquer natureza" relacionados com crimes políticos. ${ }^{23}$

O clima em torno da "abertura política" continuava tenso. A despeito do debate jurídico em andamento em torno da abrangência da anistia, em abril de 1980 tramitava no STM um pedido de punição aos três torturadores que cegaram, em fevereiro de 1976, em um presídio de Aracaju, o preso político Milton Coelho de Carvalho. Sua petição, porém, foi negada em primeira instância pelo juiz auditor da VI Circunscrição Militar, embora a violência praticada contra ele estivesse comprovada nos autos e fosse reconhecida na sentença da auditoria militar e do STM. ${ }^{24}$

No dia 27 de agosto de 1980, a secretária da OAB/RJ, Lyda Monteiro da Silva, morreu ao abrir uma carta-bomba. A carta estava endereçada ao presidente do Conselho Federal da $\mathrm{OAB}$, Eduardo Seabra Fagundes. A morte aconteceu quando a $\mathrm{OAB} / \mathrm{SP}$ e Seabra Fagundes insistiam em identificar os agentes dos serviços de segurança suspeitos de autoria do atentado sofrido pelo jurista Dalmo Dallari - sequestrado e agredido em

\footnotetext{
${ }^{23} \mathrm{O}$ parecer da seção de São Paulo da OAB apresentava uma nova redação do artigo $1^{\circ}$., especificando os contemplados pela anistia, e do $1^{\circ}$. par., incluindo os integrantes das PM demitidos, além da supressão do par. $2^{\circ}$. do projeto de Lei de Anistia. Idem, ibidem, p. 450-51.

${ }^{24}$ José, Otto. “Os torturadores anistiados. Como está sendo aplicada a Lei de Anistia". Movimento, São Paulo, 14 a 20 abr. 1980.
}

Um balanço crítico da redemocratização no Brasil 
2 de julho de 1980, em São Paulo. Este processo terminou arquivado e, cerca de 4 mil pessoas participaram dos protestos durante o enterro de Lyda. ${ }^{25}$

\section{Novas disputas: as denúncias sobre a 'Casa da Morte' em Petrópolis}

O debate sobre a punição aos torturadores voltou ao cenário político no dia 3 de fevereiro de 1981, quando Inês Etienne Romeu, ex-dirigente da Vanguarda Popular revolucionária (VPR), denunciou a localização da casa onde fora torturada durante 99 dias em 1971, em Petrópolis (RJ). Na casa funcionou um centro clandestino de tortura e extermínio do Centro de Informações do Exército (CIE), onde desapareceram ao menos nove militantes. ${ }^{26}$ No dia 5, Inês localizou o consultório do psiquiatra e psicanalista Amílcar Lobo, ocasião em que denunciou o auxílio às torturas por ele prestado na casa de Petrópolis. A psicanalista Helena Besserman Vianna havia denunciado a atuação de Amílcar Lobo, na Argentina, em 1973, sem obter repercussão no Brasil. ${ }^{27}$ Inês iniciou também uma ação na Justiça contra Mário Lodders, o proprietário da casa.

A repercussão da denúncia ocupou as capas dos principais jornais e revistas do país. ${ }^{28} \mathrm{~A}$ resposta dos militares, transmitida por meio de notas oficiais, foi imediata. A nota do ministro do Exército, general Walter Pires, foi lida na televisão. Reagiu de maneira áspera, reforçando as dúvidas que pairavam sobre as possibilidades de finalização do processo de abertura política.

${ }^{25}$ V. Dossiê Ditadura: Mortos e Desaparecidos Políticos no Brasil (1964-1985). Op. cit., p. 712-14.

${ }^{26}$ "Inês Etienne Romeu. A única presa política que ficou de fora na anistia". Pasquim, 607, 12 a 18/01/81, p. 4-7, 26; Romeu, Lúcia. "A casa das torturas de Petrópolis". In: MolicA, Fernando (org.). 10 Reportagens que abalaram a ditadura. Rio de Janeiro, Record, 2005, p. 249-69.

${ }^{27}$ V. CoImBRA, Cecília. Guardiães da Ordem. Uma viagem pelas práticas psi no Brasil do "Milagre". Rio de Janeiro, Oficina do Autor, p. 94-107.

28 "Ex-presa política volta à casa onde afirma ter sido torturada em 1971". 
| 84 |

As disputas pela interpretação da lei de anistia de 1979

O general afirmava que havia no país uma campanha organizada para "denegrir a imagem da instituição militar" com o objetivo de lançar à execração pública militares que se envolveram em "verdadeiras operações de guerra". E ameaçava: "[...] organizações antes tão dispostas a reivindicar essa anistia [definida por ele como um ato de pacificação nacional] estavam agora empenhadas em remexer no passado, com o objetivo de prejudicar a abertura política do governo". As notas dos ministros da Marinha e da Aeronáutica tinham o mesmo teor. Muitos ficaram com a convicção de que a anistia se constituiu em um instrumento jurídico para justificar e preservar a atuação dos torturadores e que a "abertura" estaria umbilicalmente ligada ao silenciamento da história da repressão política. ${ }^{29}$

Utilizando o conceito de crime conexo, o governo ditatorial pretendeu anistiar os torturadores, sem admitir sua existência, por meio de um texto de "estilo sibilino e dissimulado", mas a questão, quando examinada por especialistas, segundo um ponto de vista jurídico, apresentou uma série de contradições. Por ocasião da denúncia da 'Casa de Petrópolis', o advogado Samuel

Jornal do Brasil, 04/02/81, p. 8; “Tortura era feita em Petrópolis. Ex-presa política indica casa onde foi torturada em 1971 por um comando paramilitar.Folha de S. Paulo, 04/02/81, p. 7; "Ex-presa reconhece casa em que foi maltratada. OAB vai pedir providências, s/d.; Juiz intima acusado por ex-presa". Jornal do Brasil, 05/02/81; "Advogado do episódio da ex-presa defende Milosky", s/d.; "Presos políticos apontam médico que os atendia". Jornal do Brasil, 07/02/81; "Comandante confirma que conhece Homem de Carvalho", Jornal do Brasil, 08/02/81, p. 22; "A torturada fala com o médico da tortura. A casa dos horrores". Isto É, 216, 11/02/81; “Crise na Psicanálise". Veja, 649, 11/02/81, p. 20-37; "Anistia e revanchismo. Os assuntos do ministro Walter Pires". Isto É, 217, 18/02/81, p. 10-5; "A reação dos militares". Veja, 650, 18/02/81, p. 14-9; "Anistia ou não?". Visão, 8, 23/02/81.

${ }^{29}$ PINTO, Tão Gomes. "O antirrevanchismo. Os ministros militares, Walter Pires à frente, reagem às denúncias de torturas e deixam claro que este é um assunto proibido". Isto É, 217, 18/02/81, p.10-11.

Um balanço crítico da redemocratização no Brasil 
MacDowell foi um dos que discutiu a questão do crime conexo na Lei da Anistia, destacando que o elemento subjetivo que caracteriza cada crime, o principal e o conexo, tem de ser o mesmo. Para ele, o crime conexo seria "[...] o crime de um cidadão que rouba um automóvel para praticar um assalto a banco com finalidades políticas." No caso, entre torturadores e torturados "não haveria essa identidade de elementos subjetivos." 30

Diante da reabertura do tema, das controvérsias geradas e das pressões militares, Inês Etienne divulgou uma declaração afirmando inexistirem propósitos revanchistas de sua parte e que confiava na política de pacificação nacional. Esta declaração e o recuo da imprensa, que passou a condenar o revanchismo, acalmaram a situação. Neste clima, organizou-se uma reunião e entrevista coletiva na sede da $\mathrm{OAB}$, com os familiares dos militantes desaparecidos na 'Casa de Petrópolis'. Na ocasião, setores da esquerda, tais como os dirigentes do PCB, pronunciaram-se contrários à punição dos torturadores. ${ }^{31}$

O senador Paulo Brossard, em longo discurso no Senado, reafirmou a tese de que houve anistia para os torturadores, defendeu que Inês Etienne e todos os que sofreram tortura, mesmo os anistiados por terem cometido "crimes contra a segurança nacional", deveriam e poderiam pleitear reparações em ações cíveis, dando um tom conciliatório à polêmica e às ameaças. Não deixou de ressaltar a necessidade de suspender o segredo sobre as violências e abusos cometidos. ${ }^{32}$

Em seguida, no dia 30 de abril de 1981, ocorreu o frustrado atentado à bomba no Riocentro, quando da comemoração do dia do trabalhador. Diversos atentados desse tipo já haviam atingido entidades e bancas de jornais. Entre a sanção da Lei de Anistia de 1979 e o atentado foram detonadas aproximadamente

${ }^{30}$ Idem, ibidem, p. 11-13. Grifos meus.

${ }^{31} I d$., Ib., p. 13; “O PC contra o revanchismo”. Isto É, 217, 18/02/81, p. 14.

${ }^{32}$ Brossard, Paulo. Anistia e torturas. Brasília/DF, Senado, 17/03/81, p. 5. 
| 86 |

As disputas pela interpretação da lei de anistia de 1979

cem bombas no Rio de Janeiro e São Paulo. A presença da imprensa neste momento foi fundamental para revelar e esclarecer parcialmente os fatos. De imediato, o comando do I Exército tomou medidas para construir uma versão que ocultasse a presença de militares de DOI-CODI/RJ e de outra bomba no carro que explodiu no Riocentro. Em julho de 1981 o Inquérito Policial Militar que investigava o caso foi arquivado.

Uma reviravolta, porém, ocorreu em 8 de outubro de 1985, sob o governo do presidente civil José Sarney, quando teve início outro IPM para apurar o caso Riocentro. No dia 26 de novembro, o Congresso Nacional aprovou a emenda constitucional $n^{-} 26$, que incluiu os militares entre os anistiados. Em 1988, a mesma emenda foi utilizada para negar o pedido de reabertura da investigação sobre o Riocentro. Outras tentativas de reabri-las foram mal sucedidas. ${ }^{33}$

\section{Às vésperas da Constituinte: reaberta a polêmica sobre a anistia}

A polêmica sobre a anistia aos torturadores foi reaberta pelas declarações feitas por Amílcar Lobo, entre 1986 e 1987, quando se prontificou a contar o que sabia e a indicar o local onde teria sido enterrado Rubens Paiva, deputado cassado e desaparecido desde 1971. Na ocasião, ele reuniu-se com familiares de desaparecidos políticos a fim de fornecer-lhes informações a respeito de seus parentes. ${ }^{34}$ Neste momento, reacendeu-se o debate acerca da conexão entre os crimes

\footnotetext{
${ }_{33}$ As outras tentativas de reabertura do inquérito ocorreram em 1991, 1996 e 2000. Antunes, Priscila. Bomba en Ríocentro: militares y otras memorias. In: Hershberg, Eric e Agüero, Felipe. (comps.) Memórias militares sobre la repressión em el Cono Sur: visiones en disputa en dictadura y democracia. Espanha/Argentina, Siglo Veintiuno, 2003., p. 95 e segts.

34 "Polícia vai ouvir médico que viu Rubens Paiva à morte". Jornal do Brasil, 01/09/86; Barros, Jorge Antônio. "Médico promete contar tudo o que viu no DOI". Jornal do Brasil, 02/09/86, p. 15; STAL, Bella. "Lobo revela que
} 
considerados políticos e os dos torturadores, e ainda, sobre sua possível punição a partir de outras interpretações da Lei de Anistia. Novamente, a questão da responsabilização penal e individual dos crimes cometidos pela repressão política foi deixada de lado, apresentando-se como possibilidade de desenlace para essa questão a responsabilização civil e coletiva do Estado.

Diversos advogados afirmaram que a tortura era crime comum e não havia como caracterizá-la como conexa aos crimes políticos praticados durante a ditadura. Hermann Baeta, o presidente do Conselho Federal da OAB, considerou viável a punição criminal dos torturadores, pois o Código Penal não definia a tortura como crime, mas qualificava seus efeitos: "No caso extremo da tortura que tenha resultado em morte o prazo de prescrição é de 20 anos. [...] nada impede a apuração dos fatos, até porque um tribunal só pode decretar a anistia nos autos de um processo. E há implicações civis cujo cumprimento também decorre [dessa] apuração." ${ }^{35}$

Seabra Fagundes, ex-presidente da OAB, declarou que a Lei de Anistia não beneficiava os torturadores, embora reconhecesse que haveria dificuldades para a apuração dos fatos: "Foi essa a intenção, só que o governo não teve coragem de assumir o ônus. Então, fez uma lei nebulosa. Contudo, a matreirice do legislador não atingiu o objetivo. Até agora a interpretação oficial foi um sucesso, mas uma análise rigorosa dirá que a verdade é outra". Lembrou que, segundo o direito criminal, o conceito de conexão pressupõe a solidariedade entre os agentes: "Há conexão entre quadrilha e roubo, entre furto e receptação, mas não entre uma ação e a repressão a ela". ${ }^{36}$

PE fazia julgamento de preso político". Jornal do Brasil, 19/04/87, Cidade, p. 7. "Lobo se oferece para desenterrar presos políticos e promotor confirma informação". Jornal do Brasil, 27/04/87, Cidade, p.1.

${ }^{35}$ Moretzshon, Sylvia. Op. cit., p. 8.

${ }^{36} \mathrm{Idem}$, ibidem. Grifos meus 
| 88 |

As disputas pela interpretação da lei de anistia de 1979

Sigmaringa Seixas, advogado de presos políticos, expresidente do CBA/Brasília e deputado federal, ponderou que os torturadores não poderiam invocar em seu favor a Lei de Anistia, porque: "Esta lei só se refere a crimes de natureza política, enquadrados na Lei de Segurança Nacional, e normalmente praticados por aquele segmento a que se deu o nome de subversivos". E lembrou: considerada pela ONU como crime contra a humanidade, a tortura não era cogitada pelo Código Penal, mas em 1985 o ex-presidente Sarney assinou o parecer da ONU - ratificado pelo Congresso - contra a tortura. A reação das Forças Armadas à repercussão do depoimento do psiquiatra Amílcar Lobo, transmitida em nota oficial do Ministério do Exército, assegurou que as investigações sobre o desaparecimento de Rubens Paiva não obtivessem a incriminação penal. ${ }^{37}$

Os debates suscitados em decorrência da divulgação de denúncias da violência da ditadura e as supostas crises institucionais criadas não conseguiram reverter a impunidade. Dada a complexidade das argumentações, as discussões jurídicas se mantiveram em círculos reduzidos, inviabilizando uma ampla compreensão sobre a Lei de Anistia. Havia muitas dúvidas a respeito da abrangência da lei, não somente entre os advogados, mas principalmente entre os familiares, sobreviventes e militantes. Em 1985, no início do governo Sarney, investigações, protestos e debates ocuparam a imprensa sobre a questão dos desaparecidos políticos, principalmente, quando do lançamento do livro Brasil: Nunca Mais, contendo denúncias de torturas, baseadas em documentos da Justiça Militar. O Ministério Público não deu início a nenhuma investigação ou ação penal a respeito. As tentativas dos familiares de mortos e desaparecidos de constituir uma Comissão Parlamentar de Inquérito (CPI) haviam

\footnotetext{
${ }^{37}$ BARROS, Jorge Antônio. "Lei desconhece o crime de tortura". Jornal do Brasil, 02/09/86, p. 15. Não foram encontrados os restos mortais de Rubens Paiva e ainda não se chegou à sentença final da ação civil iniciada por sua família.
} 
fracassado em 1975 e 1979. Assim, os familiares continuaram a interpor ações declaratórias similares à ação judicial da família de Vladimir Herzog, que obteve sentença vitoriosa em 1978.

A retomada do debate sobre a anistia: A Lei dos Desaparecidos

Anos depois - após o impacto da abertura da vala clandestina do cemitério de Perus, em 1990, e a abertura dos arquivos dos DEOPS do Paraná, São Paulo e Rio de Janeiro -, durante o debate gerado pelo anúncio da Lei dos Desaparecidos (lei 9.140/95), a questão sobre a abrangência da anistia reapareceu, pois a lei definia que a aplicação de suas disposições e "[...] todos os seus efeitos orientar-se-ão pelo princípio de reconciliação e de pacificação nacional, expresso na Lei de Anistia". ${ }^{38}$

O jurista Fábio Konder Comparato ressaltou os limites morais e jurídicos da Lei dos Desaparecidos, utilizando-se do direito internacional vigente que "[...] impõe aos Estados em cujo território ocorreram desaparecimentos forçados de opositores políticos três deveres fundamentais: o de investigar os fatos e apurar a verdade sobre as circunstâncias dos desaparecimentos, com a identificação dos responsáveis; o dever de indenizar as famílias das vítimas; e o dever de punir os culpados". ${ }^{39}$

Comparato questionou a legitimidade da Lei de Anistia, ao observar que a Resolução 47/133 da Assembléia Geral da ONU e a Convenção Interamericana sobre Desaparecimentos Forçados de Pessoas da OEA reputam que as anistias não podem apagar tais crimes, sobretudo se essas leis foram votadas sob o regime

${ }^{38}$ Ver lei 9.140/95, disponível em <www.desaparecidospoliticos.org.br>

${ }^{39}$ Comparato, Fábio K. “O que fizeste de teu irmão?" In: Teles, Janaína (org.).

Mortos e desaparecidos políticos: Reparação ou impunidade? 2a ed., São Paulo, Humanitas/FFLCH-USP, 2001, p.66. Grifos meus; e "A responsabilidade do Estado brasileiro na questão dos desaparecidos durante o regime militar". In: Teles, Janaína (org.). Op. cit., p. 57-59, 61. 
| 90 |

As disputas pela interpretação da lei de anistia de 1979

que os propiciou. Ressaltou que "[...] o atual Estado brasileiro, legitimado pela promulgação da Constituição de 1988, não deve responder pelos atos praticados pelas autoridades estatais durante o regime militar". ${ }^{40} \mathrm{E}$ complementou: "O que importa frisar é o fato de que nenhum órgão do Estado brasileiro tinha legitimidade política para conceder essa anistia aos criminosos do Estado. Somente o povo poderia fazê-lo. Mas o povo continua até hoje marginalizado da vida política [...]."41

O jurista questionou também a legalidade da anistia de 1979:

A Constituição Federal de 1988 [...] declara que a tortura é considerada pela lei como crime inafiançável e insuscetível de graça ou anistia (art.5…43). Ora, se assim é em relação à tortura, com maior razão deve ser em matéria de desaparecimento forçado de pessoas, crime sem dúvida mais ignominioso que o da tortura [...]. Justamente pelo fato de que a Constituição de 1988 restabeleceu o Estado de Direito em nosso País, é dever das autoridades estatais do presente, a começar pelo Ministério Público e o Judiciário, reexaminar a validade das leis editadas durante o regime militar, à luz dos princípios fundamentais proclamados no art. $1^{\circ}$. da Constituição e das normas internacionais sobre Direitos Humanos. [... $]^{42}$

E recuperou a questão da conexão delitiva e sua relação com os crimes políticos:

\footnotetext{
${ }^{40}$ Comparato, Fábio K. "A responsabilidade do Estado brasileiro na questão dos desaparecidos durante o regime militar". In: Teles, Janaína (org.). Op. cit., p. 59; e "O que fizeste de seu irmão", Op.cit., p.67.

${ }^{41}$ Comparato, Fábio K. "A verdade republicana”, Reportagem, 65, fev./2005, p. 45.

${ }^{42}$ Comparato, Fábio K. "A responsabilidade do Estado brasileiro na questão dos desaparecidos durante o regime militar". In: Teles, Janaína (org.). Op. cit., p. 60.
}

Um balanço crítico da redemocratização no Brasil 


\begin{abstract}
A expressão 'crimes políticos', obviamente, designa os crimes contra a segurança nacional, definidos e apenados sucessivamente, durante o período de tempo determinado na lei 6.683, pela lei $\mathrm{n}^{\mathrm{o}} 1.802$, de 1953, pelo decreto-lei $\mathrm{n}^{\circ}$ 314, de 1967, e pelo decreto-lei no ${ }^{\circ}$ 898, de 1969. Nenhum desses diplomas legais incluiu, entre os crimes contra a segurança nacional, o homicídio praticado por agentes policiais ou militares, a tortura de presos, ou o desaparecimento forçado de pessoas. [...] A conexão delitiva pode ser considerada sob o aspecto material ou procedimental. No primeiro caso, ela é reconhecida quando existe um liame entre os vários crimes praticados pelo mesmo agente, em concurso material. Esse liame [...] pode ser de natureza teleológica, consequencial ou simplesmente ocasional. Mas, obviamente, só se reconhece a conexão material quando o agente ou os agentes criminosos (co-autoria) são os mesmos. Não existe concurso algum entre os crimes contra a segurança nacional imputados às vítimas de desaparecimento forçado e a prática deste último delito: os agentes são diversos, a motivação é diferente, os objetivos são distintos. ${ }^{43}$
\end{abstract}

\footnotetext{
${ }^{43}$ No caso da conexão procedimental, Comparato assinalou que esta "ocorre quando duas ou mais infrações são praticadas 'por várias pessoas, umas contra as outras'. [...] os processos devem correr perante o mesmo juízo, por razões de economia processual (facilidade de prova e de compreensão dos motivos que moveram os agentes), bem como de coerência de julgamento. [...] Não faz o menor sentido imaginar que o legislador tenha definido o âmbito de uma anistia por razões meramente procedimentais; tanto mais que, no caso dos crimes praticados pelas chamadas forças de segurança contra os opositores ao regime militar, os autores jamais chegaram a ser oficialmente identificados e, menos ainda, processados criminalmente. Não havia, portanto, processo sem curso contra os responsáveis por torturas e desaparecimentos forçados a serem eventualmente reunidos no mesmo juízo." Idem, ibidem, p. 61-2. Grifos meus.
} 
| 92 |

As disputas pela interpretação da lei de anistia de 1979

Apesar da análise contrária de diversos juristas e advogados, a interpretação de que os crimes dos torturadores seriam conexos aos dos presos políticos tem prevalecido, a responsabilidade penal e individual do agente público não foi considerada assunto pertinente para os tribunais brasileiros, muitas vezes utilizando-se do argumento de que a lei penal não pode retroagir em prejuízo do réu. ${ }^{44}$

As ações judiciais de responsabilização civil, não chegaram ao término ou não conseguiram obter execução da sentença definitiva, como no caso da ação declaratória iniciada pelos familiares de desaparecidos da Guerrilha do Araguaia em 1982, cuja sentença foi obtida em 1987. As demandas por verdade e justiça têm sido proteladas por todos os governos civis instaurados desde o fim da ditadura. Pouco se esclareceu sobre as circunstâncias dos crimes cometidos durante o período de exceção. E persiste o segredo quanto aos fatos relacionados à repressão política. ${ }^{45}$

Este debate e disputas pela interpretação da Lei de Anistia foram retomados pela ADPF 153, de autoria de Fábio K. Comparato, e proposta pelo Conselho Federal do OAB ${ }^{46}$

Ao julgar improcedente a demanda da ADPF 153, a corte suprema destacou o momento histórico vivido em 1979, ocultando uma série de fatos e conflitos. O projeto de Lei de

\footnotetext{
${ }^{44}$ V. Bicudo, Hélio. "Lei de Anistia e crimes conexos". In: Teles, Janaína (org.). Op. cit.

${ }^{45} \mathrm{O}$ presidente Lula sancionou a Lei 11.111, em 2005, estabelecendo que os documentos cujo sigilo seja "imprescindível à segurança da sociedade e do Estado" podem ficar indefinidamente vedados à consulta. Essa lei fere o "direito à verdade", garantido pela Constituição de 1988. V. Weichert, Marlon A. "O direito à verdade e os arquivos sigilosos", disponível na página Desarquivando o Brasil, no site <www.desaparecidospoliticos.org.br>.

${ }^{46} \mathrm{~V}$. “OAB: julgamento da ADPF 153 objetiva recompor dignidade do Estado brasileiro perante as nações", em <http://www.jusbrasil.com.br/noticias/ 2167601/oab-julgamento-da-adpf-153>.
}

Um balanço crítico da redemocratização no Brasil 
Anistia imposto pela ditadura se transformou em consenso entre vencedores e vencidos. A história foi, mais uma vez, reescrita. A corte, ao invés de analisar a Lei de Anistia sob o espírito da Constituição de 1988 ou do Direito Internacional de Direitos Humanos, e estabelecer definitivamente uma ruptura com o passado de ditadura, assumiu uma posição anacrônica, desconsiderando as transformações políticas, econômicas e sociais ocorridas no Brasil e no mundo (mas nem tanto!). A "ameaça militar" continua a servir de pretexto para evitar mudanças no país. ${ }^{47}$

${ }^{47} \mathrm{O}$ não cumprimento pelo Estado brasileiro da sentença da ação dos familiares dos desaparecidos da Guerrilha do Araguaia e o julgamento da ADPF 153 foram objeto de análise de sessão da Corte Interamericana de Direitos Humanos da OEA, em maio de 2010. A decisão da Corte sobre a demanda a respeito da Guerrilha do Araguaia será divulgada em 2010. 